\title{
DIE WEERGAWE VAN ADONAJ IN 'N BYBELVERTALING
}

A H VAN ZYL

In drie van sy bylaes verwys die deputate van die Gereformeerde Kerk van die Klassis Pretoria-Sentraal na die feit dat die Nuwe Afrikaanse Bybelvertaling (NAV) geen verskil maak tussen die vertaling van adonaj en die Verbondsnaam Jahweh nie. Daardeur sou die verbondsleer van die Skrif dan in die gedrang kom (vgl. Bylaes $A, 1-2 ; C, 9-11$ en $D, 5$ ). As voorbeeld kies die opsteller(s) van bylaag $A$ dan $1 \mathrm{Kon}$. 3:5 om te verduidelik hoe die NAV se weergawe probleme skep "in die deurgee van die betekenis van die oorspronklike."

Ek vermoed die opstellers het hulle hierin laat lei deur die "kunsmatige" onderskeid van Van Gelderen in die gebruik van die drie name JHWH, Elohim en Adonaj in 3:5-15. Natuurlik is dit in die algemeen waar dat dié drie name elk 'n eie aksent gehad het, en dat daar wel tekste in die Ou Testament is waar 'n doelbewuste keuse uitgeoefen is. Maar dit geld tog nie van elke teks nie, veral nie in $1 \mathrm{Kon}$. 3:5-15 nie. Na die indrukwekkende betoog van die opsteller(s) van die bylaag, eindig dit met die woorde: "Nou verskyn God aan Salomo as Jahweh en nie as Adonai (vers 10) of Elohim (vers 5) nie - wat beteken: God sorg vir Israel." En nou vra ek vir dié geleerde deputate: "Hoe moet die Naam "God" terugvertaal word in die Hebreeus? Is dit Jahweh wat sorg of Elohim?" Ons kan tog aanvaar dat dit hier waar dit gaan om die voortbestaan van Israel (en die Dawidshuis) ' $n$ verbondsaangeleentheid is. Sou hulle nie moes sê "Die Here sorg vir Israel" nie? Maar aan die ander kant moet daarop gelet word dat die naam Jahweh ook draer is van die boodskap dat Hy magtig is en "in staat is om aan Salomo enigiets te gee" (volgens die deputate kan net God die Almagtige, dus Elohim dit doen). Daarom vra ek of die man wat die lied van Moses vir ons verwoord het onder die hand van die Gees van God net so oningelig, onregsinnig en verbondslos was as die eindredaksie van NAV? In Eks. 15:1-18 word die naam Jahweh deurgaans in 'n konteks gebruik waar dit gaan om die mag van die Here, nie net oor Egipte se oorlogskarre en leër nie, maar ook oor die skeppingselemente: seewater, aarde en wind. Hoekom is die naam Elohim "die Skepper van hemel en aarde" 1 " nie in 15:4-5, 10 gebruik nie? En as Van Gelderen en die deputate se opvatting oor die gebruik van Adonaj dan so konsekwent deurgevoer is in die Ou Testament, moes die lied van Moses 
ook 'n plekkie gehad het vir Adonaj "de Opperheer"2) wie se keuse vir Israel gekontrasteer moes word met wat sy vyand sê (9). Dit is merkwaardig hoe Van Gelderen en sy navolgers, die Gereformeerde deputate, 1 Kon. 3:5-15 se gebruik van die name Jahweh, Elohim en Adonai net volg so ver as dit in hulle argument pas. In 3:15 is Salomo terug in Jerusalem en daar gaan staan hy voor die 'a ron berrt a donaj: die verbondsark van Adonaj, nie van Jahweh nie. Ja, ook Adonaj het met die verbond te maak. Hy is nie "Opperheer" los van die verbond nie. By die inlê van gedagtes en betekenisse en die wisselende naamgebruik moet ons oppas dat ons nie later as't ware "drie gode" in 1 Kon. 3:15 kry nie: 'n Verbondsgod, 'n Skeppergod en 'n Oppergod. Dié soort skrifuitleg herinner aan Joodse midrasj. ${ }^{31}$

Moet daar in 'n psalm soos Ps. 68 nóú aan die Skeppergod, dán aan die Verbondsgod en dán weer aan die "Opperheer" gedink word? Vir enige welmenende Bybelleser, teoloog of kommentaarskrywer is dit tog duidelik dat die feesoptog waarna 68:25 verwys, bestaan uit lede van die verbondsvolk: sangers, meisies en lede van die volk. Hulle sing God se lof, en in 68:26 is Elohim en Jahweh as sinonieme gebruik. Dit gebeur dikwels in die psalms. Of loof die sangers in diens van die verbondsheiligdom waar hulle altyd gesing het "Loof die Here" (vgl. 1 Kron. 16:7) nou ewe skielik die Skeppergod?

Maar om terug te kom na die weergawe van die woord Adonaj en daarmee saam die naam Jahweh waaroor die hele Gereformeerde Kerk so gaande is. Heiberg ${ }^{4}$ het reeds die aandag van sy kerkgenote gevestig op die probleme wat Bybelvertalers het met die weergawe van die name Jahweh en Adonaj. Die deputate kies vir die tradisionele weergawe van die vier konsonante JHWH met: "die HERE" in navolging van die besluit van die Dordtse Sinode wat by gebrek aan ' $n$ beter woord besluit het op die woord "Heere" wat dan met hoofletters geskryf moet word: "HEERE". So is dit gedoen in die Statevertaling, en op die hoofletters is waarskynlik besluit na aanleiding van die skryfwyse LORD in die Authorised (King James) Version van 1611.5) Dit is opvallend dat Luther hierin aansluit by 'n Bybelse vertaaltradisie wat in die Nuwe Testament opgeneem (en gesanksioneer) is. Die Griekse vertaling (die LXX) het $\mathrm{JHWH}$ naamlik vertaal met Kurios, en so is dit weergegee in Ou-Testamentiese aanhalings in die Nuwe Testament. Hiervan is Matt. 22:44 'n goeie voorbeeld. Dit is ' $n$ aanhaling uit Ps. 110:1, maar volgens die $L X X-$ vertaling (109:1), wat die Hebreeuse woorde Jahweh en Adonaj albei met Kurios weergee. Ook die Vulgaat gebruik in albei gevalle "Dominus". Daarom vertaal Luther Ps. 110:1 "Der Herr sprach zu meinem Herrn." 6 ) Daarteenoor het die Authorised Version onderskei tussen "LORD" en "Lord", die Statevertaling tussen "HEER" en 
"HERE" en "Here", onderskeidings wat slegs vir die ingeligte leser iets te sê mag hê. Die hoorder wat na die Woord luister, merk niks van hierdie optiese tegniek nie. Dieselfde geld van die oningeligte leser wat dan in Matt. 22:44 in die Statevertaling lees: "De HEER heeft gezegd tot mijnen Heer", of in die 1933-vertaling: "Die HERE het vir my Here gesê." Sou die Bybelleser nie kon vra (en dit geld van die hele Nuwe Testament): "Wat het van die HERE van Ps. 110:1 (en van die res van die Ou Testament) in die Nuwe Testament geword?" nie.

Die vertalers van NAB het nie ligtelik met die weergawe van die name van God te werk gegaan nie. Tekens van hulle worsteling is byvoorbeeld te sien in die proefvertaling van 1970. Maar uiteindelik is hulle gelei deur dieselfde beginsel as dié waardeur die Vulgaat, die Erasmusvertaling van die Nuwe Testament en Luther gelei is. En die beginsel is daarin te vind dat die Nuwe Testament nie net die vertaling van die naam Jahwe gesanksioneer het nie, maar ook vir ons geleer het om dit te doen soos die LXX dit gedoen het. Daarom het ons nié, soos bg. deputate voorskryf, die naam Jahweh onvertaald opgeneem nie.

Maar wanneer sowel Jahweh as Adonaj met die Here, eg. met of sonder vier hoofletters geskryf, weergegee word, kom vertalers voor 'n nuwe probleem te staan. Deurdat die vorm Adonaj Jahwe (of: Jahweh Adonaj) voorkom (bv. Jos. 7:7, Rig. 6:22) ontstaan die on-Afrikaanse vorm Here HERE (of die Here HERE, bv. Eseg. 3:27). In die LXX is dié kombinasie op verskillende maniere gehanteer. In Jos. 7:7 is net kurios (Vokatief) gebruik, maar in Rig. 6:22 is die vokatief van kurios herhaal vir dieselfde Hebreeus as in Jos. 7:7. In 2 Sam. 7:18-29 is die besitlike voornaamwoord saam vertaal kurié mou kurié. Wat hier opvallend is, is dat Stuttgartensia en LXX dieselfde lesing het in 7:22 terwyl Kittel lees: Jahwe Elohim, Here God, soos in 1933 vertaal. Dit dui op wissellesing (waarvan Stuttgartensia die betroubaarste is ten spyte van wat bg. deputate beweer) waarin die name Jahweh, Elohim en Adonaj uitruilbaar was omdat hulle in baie tekste bloot sinonieme was.

Die drie vertaalwyses van LXX in Jos. 7:7, Rig. 6:22 en 2 Sam. 7:18-29 kan verklaar word deur die feit dat dit drie vertalers se sienswyses weergee. Maar in Esegiël waar die kombinasie Adonaj Jahweh dikwels voorkom, en waar vir LXX net een vertaler te veronderstel is, is die kombinasie op verskillende maniere weergegee. Aangesien die kombinasie so baie voorkom in Esegiël (meer as die helfte van die gevalle waar Adonaj gebruik word in die O.T. kom in Esegiël voor), is slegs 'n paar steekproewe gedoen. Die veertien voorbeelde wat gekontroleer is in Eseg. 3:27-12:28, is op drie maniere vertaal. Twaalf keer is net met kurios (of kurié) vertaal, een keer (4:14) met die vokatief kurié théé, en een keer is kurios herhaal. Dit is opvallend dat die aanspraak in die klag 
(4:14; 9:8; 11:13) waar ' $n$ herhaling van kurios vir die taal-oor aanvaarbaar sou wees, óf net met kurie $(9: 8 ; 11: 13)$ óf met kurié théé weergegee is.

In NAV is die kombinasie Adonaj Jahweh (of Jahweh Adonaj) in die reël met "die Here my God" (of Here my God) weergegee. In dié verband is ' $n$ aanbeveling van die Dordtse Sinode waarop ek onlangs eers afgekom het, interessant. "Ook zullen de overzetters vermaand worden, waar dit woord de punten heeft van het woord Elohim, te letten, of het in die plaatsen niet meer bekwaamlijk deur het woord God als door het woord HEERE zou kunnen vertaald worden".7) Onbewus van hierdie stukkie "regsinnige" advies uit Dordrecht wat gegee is op Saterdag 24 November 1618, het die NAV se eindredaksie gedoen wat tóé al oorweeg is. Waarskynlik is die Sinode gelei deur die feit dat daar in sulke gevalle nie Jahweh (of Jehova soos hulle gedink het) gelees is nie, maar Elohim of Elohaj). Dit was nie die primêre oorweging by NAV nie. Die rede agter die vertaling van NAV lê, soos reeds gesê agter die vertaalbaarheid van die naam Jahweh soos in LXX en oorgeneem deur die Nuwe Testament. Maar ' $n$ verdere oorweging is daarin geleë dat die drie name Jahweh, Elohim en Adonaj ten voile uitruilbaar is.

Wat sy taalkundige vorm betref, kan die woord adonaj óf 'n meervoud van uitgebreidheid wees soos élohim (p/uralis amplitudinis), waaraan die voornaamwoordsuitgang van die eerste persoon enkelvoud gevoeg is, óf dit kan ' $n$ vorm wees van adon waaraan ' $n$ naamwoordelike uitgang -aj gevoeg is om daaraan 'n superlatiewe betekenis te gee. In eersgenoemde geval het die voornaamwoordelike uitgang in baie gevalle verstar en sy betekenis verloor sodat sonder meer met "Here" of "die Here" vertaal kan word. In laasgenoemde geval is die -aj-uitgang mettertyd as voornaamwoordelike uitgang opgevat sodat dit in ' $n$ vertaling na vore gebring mág word.

Wat sy betekenis betref, is die woord adon primêr te beskou as ' $n$ verhoudingswoord. Dis die woord waarmee 'n mindere sy meerdere aanspreek. So kom dit ook voor in die buite-Bybelse literatuur van Amarna, Mari en Ugarit. 'n Onderdaan noem sy koning ' $d n$, en sy koningin ' $d t$. Ook die Israeliete het hulle koning adon genoem (Jer. 22:18; 34:5), en van Egipte se koning is gepraat as "'n harde adonim" (Jes. 19:4), met "'n streng mè/èk" as sinoniem daarvan. Om Egipte se koning se mag te beklemtoon, is die meervoud van uitgebreidheid gebruik (vgl. hierbo). Maar desondanks staan Egipte en sy koning onder die woord van ha'adon jhwh șeba'ot, die Here die Almagtige, die Koning.

In die omgang tussen mense is die verhoudingswoord adon o.a. gebruik deur Ragel om haar pa aan te spreek, en in NAV is dit weergegee met "Pa" (Gen. 31:35). In Gen. 24:37 verwys Abraham se slaaf na hom 
as adonr: my eienaar. Hier sou "my baas" soos dit tans ook in hoë amptenaarskringe gebruik word, 'n goeie vertaling kon wees. Dit is egter nie hier (of elders) gebruik nie omdat die "baas-slaaf"-stigma in baie kringe hinderlike assosiasies skep. In dieselfde hoofstuk spreek Rebekka die vreemdeling aan as adont: Meneer (24:18). Toe Josef se broers in Egipte met hom gepraat het, spreek hulle hom aan as adont, Meneer! (Gen. 42:10), en wanneer hulle met Josef se hoofamptenaar praat, noem hulle hom ook "Meneer" (43:20). In 44:7 is die adoni in NAV met " $u$ " weergegee.

In Gen. 32-33 doen Jakob alles in sy vermoë om Esau se goedgesindheid te wen. Hy beklemtoon dit herhaaldelik dat hy Esau se onderdaan, èbèd wil wees, en in 32:18 (MT 19) verwys Jakob selfs na Esau as adonr. In sy woordkeuse hou Jakob homself in sy verhouding tot Esau dus voor as die mindere. Esau is Jakob se meerdere (èbèd teenoor adon). Die voorste slaaf (èbèd) van Jakob moet vir Esau sê die geskenk is vir Esau, en Esau is Jakob se adon. NAV het hierdie posisie uitgedruk deur vir Jakob te laat sê dat hy "Meneer" se onderdaan wil wees.

In die Afrikaanse taal is daar verhoudingswoorde om die verhouding tussen mense te beskryf soos in die Hebreeus weergegee deur die verwysing na die meerdere as adon: pa, $u$, baas, eienaar, meneer, Koning (U, Majesteit). Maar wanneer adon na God verwys, is ons Afrikaanse woordeskat karig.

In theofore eiename dui adon daarop dat 'n mens sy god (God) adon noem. Maar hoe word die woord weergegee?

Die Bybelse eienaam ${ }^{a}$ donijjah bely óf dat Jahweh die naamgewer (-draer) se God is (My God is Jahweh) of dat Jahweh dié Een is wie se woord hy gehoorsaam, dus: Jahweh is my Hoogste Bevelvoerder, d.w.s. my God. In Eks. 23:17 waar dit gaan om die besoek aan die heiligdom op die drie groot jaarlikse feeste, word die Israeliete vermaan om drie keer per jaar te verskyn voor ha'adon jhwh, en dan moet hulle die eerste opbrengs uit hulle lande bring na die huis toe van jhwh èlohèka 13:19) waaruit blyk dat ha'adon en è/OhIm uitruilbare woorde is, en sinonieme betekenis kan hê (vgl. ook 34:23-24). Omdat Jahwe beskik oor al die nasies (dus adon, èlohtm is), sal Hy die nasies tydens die feestyd verhinder om Israel se gebied te probeer inpalm. Hy kan dit doen, want $\mathrm{Hy}$ is Jahweh. die oppermagtige God, die magtigste van alle maghebbers (Ps. 136:1, 3). In Jos. 3:13 beheer Jahweh, wat adon is van die hele aarde omdat $\mathrm{Hy}$ die Skepper is, die vloei van die Jordaan se water.

Soos adon' $n$ duidelike sinoniem kan wees van elohim soos blyk uit bg. voorbeelde, so kan dit ook die geval wees met adon en Jahweh. Dit blyk bv. uit Miga 4:13 waar die profeet vir Jahwe noem "die Koning van die hele wêreld" en uit Psalms soos 97:5 en 135:5. 'n Mens kan amper sê 
dit was van die begin van die Jahweh verering af die geval, want reeds in Eks. 15:17 word Jahweh ook aangespreek as Adonaj sonder dat daar 'n sweem van ' $n$ nuanseverskil in die twee aanspreekvorms is.

In die gewone menslike verhoudingstrukture is daar, soos hierbo aangedui, ' $n$ verskeidenheid woorde waarmee die verhouding wat deur die woord adon uitgedruk is, weergegee kan word. Wanneer die woord (ook in die vorm Adona) egter gebruik word om God (Elohim), die Here (Jahweh), se "meer as 'n mens" uit te druk, is die keusemoontlikhede beperk. Hy kan genoem word die Koning van die hele wêreld (Miga 4:13; vgl. Jes. 17:4), die magtigste (superlatief) van die maghebbers (Ps. 136:3). Maar wanneer dit van die mens se kant gaan om die erkenning dat Adonaj sy God is, die Here wat ' $n$ verbond met die mens gemaak het, bly daar net 'n keuse uit twee: God (my God, ons God) en die Here. Dit is dan ook die twee woorde wat oorwegend in NAV gebruik is. Daarvoor is daar naas die Skriftuurlike gelykstelling van Jahweh en Adonaj, of Elohim en Adonaj, ook die voorbeeld van die LXX en die NT, en vir die weergawe van Adonaj met "my God" ook die "regsinnige" suggestie van Dordt wat eers agterna "ontdek" is.

\section{Notas}

1. Vgl. C.J. Labuschagne, "Die gebruik van die Godsaanduidinge 'ề en 'elăhîm in die geskrifte van die profete", HTS 14, Afl. II en III (1959), 67-78.

2. C. van Gelderen, Koningen I, Kampen 1937, 78.

3. Vgl. R. Bascom, "Targums: Ancient reader's helps?", The Bible Trans/ator 36/3 (1985), $301-316$.

4. J.L. Helberg, "Hoe praat die nuwe vertaling?", Die Kerkblad, 8 Januarie 1984.

5. Daar was wel verteenwoordigers van Engelse kerke by die Dortsche Sinode, maar die notule verwys nie na ' $n$ aandeel van hulle i.v.m. die besluit nie.

6. Selfs waar Luther Adonaj Jahweh vertaal met "der Herr Herr" (Jos. 7:7), gebruik hy dieselfde skryfvorm.

7. Vgl. notule, 23. 